\title{
Editorial \\ Cavitation Erosion, Abrasive and Sliding Wear Behavior of Metal-Based Structures
}

\author{
Mirosław Szala (D)
}

Citation: Szala, M. Cavitation

Erosion, Abrasive and Sliding Wear Behavior of Metal-Based Structures Metals 2022, 12, 373. https:// doi.org/10.3390/met12030373

Received: 16 February 2022 Accepted: 19 February 2022 Published: 22 February 2022

Publisher's Note: MDPI stays neutral with regard to jurisdictional claims in published maps and institutional affiliations.

Copyright: (C) 2022 by the author. Licensee MDPI, Basel, Switzerland. This article is an open access article distributed under the terms and conditions of the Creative Commons Attribution (CC BY) license (https:/ / creativecommons.org/licenses/by/ $4.0 /)$.
Department of Materials Engineering, Faculty of Mechanical Engineering, Lublin University of Technology, Nadbystrzycka 36D, 20-618 Lublin, Poland; m.szala@pollub.pl

\section{Introduction and Scope}

The literature includes systematic studies of the wear behavior and phenomena responsible for a material's degradation resistance. Overall, from the broad range of deterioration processes, tribological wear, namely sliding and abrasive wear, is the dominant type of engineering material degradation. Cavitation erosion is a unique wear process that still is not entirely understood. Even though the literature on the subject explains the general factors influencing both cavitation erosion and tribological wear of structural materials, the continuous development of metal-based structures' fabrication, processing, and treatment technology demands systematic reporting on the advances in the wear properties of metallic materials. From both the scientific and engineering points of view, the wear of metallic components must be minimized to improve their reliability. The engineering industry is demanding metal-based structures that perform well in terms of cavitation erosion or tribological wear environments, or optimally to both. First, to manage that task, material wear mechanisms should be understood. To facilitate the selection and design of wear-resistant materials, computer simulation, numerical calculations, or artificial neural networks can be employed. Therefore, papers containing the experimental and numerical results combined with the effect of material properties on the cavitation, abrasion, or sliding wear resistance are included in this Special Issue.

This Special Issue, "Cavitation Erosion, Abrasive and Sliding Wear Behavior of MetalBased Structures", released by Metals, is dedicated to original research articles highlighting recent advances and future directions in the fields of cavitation erosion and abrasive and sliding wear behavior of metal-based structures, presenting some of the latest work in a few topical areas listed above. In total, seven good-quality articles have been included [1-7] regarding advances in the performance of metal-based structures.

\section{Contributions}

The present Special Issue includes seven scientific papers (Szala et al. [1], Lonkwic et al. [2], Zhao et al. [3], Podulka [4], Peng et al. [5], Gao et al. [6], and Chabak et al. [7]) mainly covering operational properties of metallic materials analyzed by experimental means. In order of publication:

- Szala et al. [1] studied the cavitation erosion and sliding wear of cold-sprayed $\mathrm{Al} / \mathrm{Al}_{2} \mathrm{O}_{3}$ and $\mathrm{Cu} / \mathrm{Al}_{2} \mathrm{O}_{3}$ coatings, stainless steel, aluminium alloy, copper, and brass.

- Lonkwic et al. [2] investigated the application of stray magnetic field for monitoring the wear degree in steel components of the lift guide rail system.

- Zhao et al. [3] investigated ultrasonic cavitation erosion behaviors of Al and Al-5Ti alloys in distilled water.

- Podulka [4] studied the improved procedures for feature-based suppression of surface texture high-frequency measurement errors in the wear analysis of cylinder liner topographies.

- $\quad$ Peng et al. [5] characterized the solid particle erosion of the sealing surface materials of a ball valve. 
- Gao et al. [6] researched the corrosion resistance of CoCrFeNiMn high-entropy alloy coating prepared through plasma transfer arc claddings.

- Chabak et al. [7] investigated structural and tribological studies of " $(\mathrm{TiC}+\mathrm{WC}) /$ hardened steel" PMMC coating deposited by air-pulsed plasma.

\section{Conclusions and Outlook}

The content of this Special Issue is addressed to a broad group of scientists and engineers working in the field of wear prevention of machine parts and components manufactured with metallic materials.

Papers focused on wear improvement via microstructural properties modification, surface layer treatment, and the deposition of wear-resistant coatings onto a metal-based substrate were included. All of these papers focus on the experimental aspects of metallic structures treatment and operational behavior. The performance of metal-based structures such as conventional metal alloys, hardfacings, thermally sprayed coatings, composites, and cast metal structures were studied. The papers confirm a need for experimental data in the field of surface engineering to understand the physical phenomena involved in the operation performance of metallic components.

The scientific papers contained in this Special Issue provide new knowledge in the fields of material science and mechanical engineering.

Funding: This research received no external funding.

Acknowledgments: As a guest editor, I would like to thank all the authors for their valuable contributions to the present Special Issue; the reviewers who supported their selection; and the editorial team of Metals, particularly Marina Tian, for their assistance and support during the preparation of this Special Issue. It has been a pleasure to act as guest editor for this Special Issue.

Conflicts of Interest: The author declares no conflict of interest.

\section{References}

1. Szala, M.; Łatka, L.; Walczak, M.; Winnicki, M. Comparative Study on the Cavitation Erosion and Sliding Wear of Cold-Sprayed $\mathrm{Al} / \mathrm{Al}_{2} \mathrm{O}_{3}$ and $\mathrm{Cu} / \mathrm{Al}_{2} \mathrm{O}_{3}$ Coatings, and Stainless Steel, Aluminium Alloy, Copper and Brass. Metals 2020, 10, 856. [CrossRef]

2. Lonkwic, P.; Krakowski, T.; Ruta, H. Application of Stray Magnetic Field for Monitoring the Wear Degree in Steel Components of the Lift Guide Rail System. Metals 2020, 10, 1008. [CrossRef]

3. Zhao, J.; Jiang, Z.; Zhu, J.; Zhang, J.; Li, Y. Investigation on Ultrasonic Cavitation Erosion Behaviors of Al and Al-5Ti Alloys in the Distilled Water. Metals 2020, 10, 1631. [CrossRef]

4. Podulka, P. Improved Procedures for Feature-Based Suppression of Surface Texture High-Frequency Measurement Errors in the Wear Analysis of Cylinder Liner Topographies. Metals 2021, 11, 143. [CrossRef]

5. Peng, D.; Dong, S.; Wang, Z.; Wang, D.; Chen, Y.; Zhang, L. Characterization of the Solid Particle Erosion of the Sealing Surface Materials of a Ball Valve. Metals 2021, 11, 263. [CrossRef]

6. Gao, P.-H.; Fu, R.-T.; Chen, B.-Y.; Zeng, S.-C.; Zhang, B.; Yang, Z.; Guo, Y.-C.; Liang, M.-X.; Li, J.-P.; Lu, Y.-Q.; et al. Corrosion Resistance of CoCrFeNiMn High Entropy Alloy Coating Prepared through Plasma Transfer Arc Claddings. Metals 2021, 11, 1876. [CrossRef]

7. Chabak, Y.; Efremenko, V.; Zurnadzhy, V.; Puchý, V.; Petryshynets, I.; Efremenko, B.; Fedun, V.; Shimizu, K.; Bogomol, I.; Kulyk, V.; et al. Structural and Tribological Studies of "(TiC + WC)/Hardened Steel" PMMC Coating Deposited by Air Pulsed Plasma. Metals 2022, 12, 218. [CrossRef] 